\title{
Response of Eight Sweet Maize (Zea mays L.) Hybrids to Saflufenacil Alone or Pre-Mixed with Dimethenamid-P
}

\author{
Darren E. Robinson*, Nader Soltani, Peter H. Sikkema
}

University of Guelph Ridgetown Campus, Ridgetown, Canada.

Email: *drobinso@ridgetownc.uoguelph.ca

Received October $6^{\text {th }}, 2011$; revised October $11^{\text {th }}, 2011$; accepted November $3^{\text {rd }}, 2011$

\begin{abstract}
Saflufenacil is a new herbicide for use in field maize (Zea mays L.) and other crops that may have potential for weed management in sweet maize. Tolerance of eight sweet maize hybrids to saflufenacil and saflufenacil plus dimethenamid-p applied preemergence (PRE) were studied at two Ontario locations in 2008 and 2009. Saflufenacil applied PRE at 75 and $150 \mathrm{~g} \cdot \mathrm{ha}^{-1}$ and saflufenacil plus dimethenamid-p (pre-mixed) applied PRE at 735 and $1470 \mathrm{~g} \cdot \mathrm{ha}^{-1}$ caused minimal (less than 5\%) injury in Cahill, GH4927, Harvest Gold, Rocker, BSS5362, GG236, GG447, and GG763 sweet maize hybrids at 1 and 2 weeks after emergence (WAE). Saflufenacil or saflufenacil plus dimethenamid-p applied PRE did not reduce plant height, cob size, or yield of any of the sweet maize hybrids tested in this study. Based on these results, saflufenacil and saflufenacil plus dimethenamid-p pre-mixed applied PRE at the doses evaluated can be safely used for weed management in Cahill, GH4927, Harvest Gold, Rocker, BSS5362, GG236, GG447, and GG763 sweet maize under Ontario environmental conditions.
\end{abstract}

Keywords: Cob Size; Height; Injury; Preemergence; Tolerance; Yield

\section{Introduction}

Sweet maize (Zea mays L.) is one of the most important field grown vegetables in Ontario [1]. In 2009, nearly 112,000 tonnes of sweet maize was produced on approximately 9000 hectares with a farm-gate value of $\$ 36$ million, and ranked as the second largest field grown vegetable crop in Ontario in terms of farm-gate value [1]. Weed control is critical in sweet maize production to maintain quality and yield and be competitive in the global market place. More research is needed to identify herbicide options that can effectively control grass and broadleaved weeds in sweet maize production.

Saflufenacil (BAS $800 \mathrm{H}$ ) is a new herbicide being developed by BASF for preemergence (PRE) broadleaved weed control in field maize (Zea mays L.), soybean (Glycine max L.) and other field and vegetable crops. Saflufenacil can control troublesome weeds such as velvetleaf (Abutilon theophrasti), common ragweed (Ambrosia artemisiifolia), giant ragweed (Ambrosia trifida), common cocklebur (Xanthium strumarium), ladysthumb (Polygonum persicaria), redroot pigweed (Amaranthus retroflexus), common waterhemp (Amaranthus tuberculatus var. rudis) and common lambsquarters (Chenopodium album) including triazine and acetolactate synthase re-

${ }^{*}$ Corresponding author. sistant biotypes [2-6].

Saflufenacil is a pyrimidinedione that inhibits protoporphyrinogen-IX-oxidase (PPO). Susceptible weeds to saflufenacil show injury symptoms within a few hours and die in 1 to 3 days [6]. Saflufenacil has both contact and residual activity against susceptible weeds and is mainly translocated in the xylem [6]. Saflufenacil is applied at relatively low doses and has low environmental, toxicological and eco-toxicological impact with minimal residual carryover and persistence in the soil [6]. The proposed dosage for sweet maize in Ontario is $75 \mathrm{~g}$ a.i. $\mathrm{ha}^{-1}$. Saflufenacil provides a novel mode of action (PPO inhibitor) for sweet maize that is different than currently used broadleaved herbicides reducing potential for the selection of herbicide resistant weed biotypes [6,7].

Saflufenacil is also compatible with residual herbicides that control grasses. BASF has developed saflufenacil plus dimethenamid-p premix (BAS781) for use in maize and other crops [6]. Dimethenamid-p is a chloroacetamide herbicide that in susceptible plants inhibits very long chain fatty acid synthesis [7]. Dimethenamid-p can provide season long control of a broad spectrum of grass and broadleaved weeds such as barnyardgrass (Echinochloa crusgalli), autumn panicum (Panicum dichotomiflorum), giant foxtail (Setaria faberi), green foxtail (Setaria viridis), yellow foxtail (Setaria glauca), large 
crabgrass (Digitaria sanguinalis), smooth crabgrass (Digitaria ischaemum), witchgrass (Panicum capillare), redroot pigweed (Amaranthus retroflexus), American black nightshade (Solanum americanum), and eastern black nightshade (Solanum ptycanthum) [2,7]. Dimethenamid-p at the registered application doses has been shown to cause little or no injury in field maize [8,9]. Saflufenacil plus dimethenamid-p can provide an effective broad spectrum herbicide option for the control of troublesome species in sweet maize.

Saflufenacil and saflufenacil plus dimethenamid-p are desirable compliments to the current weed management programs in sweet maize because of its low dosage; broad-spectrum weed control, environmental safety, and new mode of action that will help reduce selection for herbicide resistant biotypes. There is no published information on the sensitivity of sweet maize hybrids to the PRE application of saflufenacil or saflufenacil plus dimethenamid-p. If tolerance is adequate, registration of saflufenacil and saflufenacil plus dimethenamid-p will provide sweet maize growers with an additional option for annual weed control. Sensitivity of sweet maize to herbicides is dependent on the application dose, hybrid, and environmental conditions. Sweet maize hybrid sensitivity has been documented for foramsulfuron [10], bentazon [11], prosulfuron [12], mesotrione [13], nicosulfuron $[14,15]$, primisulfuron [16], isoxaflutole [17], and thifensulfuron-methyl [18].

The objective of this study was to determine the sensitivity of Cahill, GH4927, Harvest Gold, Rocker, BSS5362, GG236, GG447, and GG763 sweet maize to saflufenacil and saflufenacil plus dimethenamid-p applied PRE under Ontario environmental conditions.

\section{Materials and Methods}

Field experiments were conducted at the University of Guelph, Ridgetown Campus, Ridgetown, Ontario and the Huron Research Station, Exeter, Ontario in 2008 and 2009. The soil at the Ridgetown location was a Watford/ Brady loam composed of $51 \%$ sand, $32 \%$ silt, $16 \%$ clay, and $5.5 \%$ organic matter with a $\mathrm{pH}$ of 7.2 in 2008 and $49 \%$ sand, $34 \%$ silt, $17 \%$ clay, and $9.2 \%$ organic matter with a $\mathrm{pH}$ of 7.2 in 2009. The soil at the Exeter location was a Brookston clay loam composed of $34 \%$ sand, $36 \%$ silt, $30 \%$ clay, and $3.6 \%$ organic matter with a $\mathrm{pH}$ of 8.0 in 2008 and $39 \%$ sand, $37 \%$ silt, $24 \%$ clay, and $4.3 \%$ organic matter with a pH of 7.9 in 2009 . Seedbed preparation consisted of moldboard plowing in the fall and cultivation in the spring. Fertilizer was broadcast and incorporated prior to seeding based on soil tests and local recommendations.

There were two experiments established side by side at each site (one evaluating saflufenacil and the other evalu- ating saflufenacil plus dimethenamid-p). The experiments were arranged in a split-plot design with four replications. The main plots were herbicide dose, and the subplots were sweet maize hybrids. Selection of herbicide doses was based on the manufacturer recommended use dose and twice the manufacturer recommended dosage.

Treatments consisted of a non-treated check and two doses of saflufenacil $\left(0,75\right.$ and $150 \mathrm{~g}$ a.i. $\left.\mathrm{ha}^{-1}\right)$ or saflufenacil plus dimethenamid-p $\left(0,735\right.$ and $1470 \mathrm{~g}$ a.i. $\left.\mathrm{ha}^{-1}\right)$ representing the untreated control and the $1 \mathrm{X}$ and $2 \mathrm{X}$ of the proposed label dose, respectively. Eight of the most commonly grown processing sweet maize hybrids in southwestern Ontario encompassing a range of endosperm genotypes were selected: Cahill (su), GH4927 (su), Harvest Gold (su), Rocker (su), BSS5362 (sh $\left.h_{2}\right)$, GG236 (su), GG447 (su), and GG763 (su) sweet maize. Each of the main plots was $6 \mathrm{~m}$ wide by $8 \mathrm{~m}$ long at Ridgetown and 6 $\mathrm{m}$ wide by $10 \mathrm{~m}$ long at Exeter. The subplots each consisted of a single row of each sweet maize hybrid with rows spaced $75 \mathrm{~cm}$ apart. The sweet maize was thinned to 50,000 plants $\mathrm{ha}^{-1}$ shortly after emergence. The plots were then kept weed-free using inter-row cultivation and hand hoeing as required.

Herbicide treatments were applied PRE four to eight days after planting using a $\mathrm{CO}_{2}$-pressurized backpack sprayer calibrated to deliver $200 \mathrm{~L}$ aqueous solution at $241 \mathrm{kPa}$. The boom was $1.5 \mathrm{~m}$ wide with four ULD12002 nozzles (ULD120-02 nozzles tip; Spraying Systems Co., Wheaton, IL.) spaced $0.5 \mathrm{~m}$ apart.

Crop injury including stand reduction was evaluated visually comparing the non-treated hybrid to the respective treated hybrids on a scale of 0 to $100 \%$ at 1 and 2 weeks after emergence (WAE). A rating of $0 \%$ was defined as no visible effect of the herbicide and $100 \%$ was defined as plant death. Average maize height (based on ten random plants per subplot) was measured for each subplot 3 WAE. The height of the plant was defined as the maximum height from the soil surface with the leaves fully extended. At maturity, each subplot was harvested by hand and cob size, marketable yield (a cob greater than $5 \mathrm{~cm}$ in diameter) and total yield were recorded. Because the results of the statistical analyses for total and marketable yields were similar, only marketable yield is reported.

All data were subjected to analysis of variance (ANOVA). Tests were combined over locations and years and analyzed using the PROC MIXED procedure of SAS (Statistical Analysis Systems Institute, Cary, NC, USA). Variances of percent crop injury at 1 and 2 WAE, plant height, cob size, and yield were partitioned into the fixed effects of herbicide treatment, hybrid, and herbicidehybrid interaction and into the random effects of siteyear, block (site-yr), site year-treatment, site year-hybrid and site year-hybrid-treatment. Significance of random 
effects was tested using a Z-test of the variance estimate and fixed effects were tested using F-tests. Error assumptions of the variance analyses (random, homogeneous, normal distribution of error) were confirmed using residual plots and the Shapiro-Wilk normality test. To meet the assumptions of the variance analysis, visual injury at 1 and 2 WAE were subjected to an arcsine square root transformation and cob size data were log transformed. No transformation was required for plant height or yield. Treatment means were separated using Fisher's protected LSD test. Means of percent injury and cob size were compared on the transformed scale and were converted back to the original scale for presentation of results. Type I error was set at $\mathrm{P} \leq 0.05$ for all statistical comparisons.

\section{Results and Discussion}

Statistical analysis of the data on visible injury, plant height, cob size and yield showed that the random effects of location, year, year by location and interactions with treatments were not significant. Therefore, data were pooled and averaged over years and locations (Tables 14).

Table 1. Injury at 1 and 2 weeks after emergence (WAE) of eight sweet maize hybrids treated prior to emergence with saflufenacil at 0,75 , and $150 \mathrm{~g} \cdot \mathrm{ha}^{-1}$ or saflufenacil plus dimethenamid-p at 0, 735, and $1470 \mathrm{~g} \cdot \mathrm{ha}^{-1}$ at Exeter, $\mathrm{ON}$, and Ridgetown, ON, in 2008 and 2009.

\begin{tabular}{|c|c|c|c|c|}
\hline \multirow{2}{*}{ Treatment/Hybrid $^{\mathrm{a}}$} & \multicolumn{2}{|c|}{ Injury 1 WAE } & \multicolumn{2}{|c|}{ Injury 2 WAE } \\
\hline & $75 / 735^{b}$ & $150 / 1470^{b}$ & $75 / 735^{b}$ & $150 / 1470^{b}$ \\
\hline & \multicolumn{4}{|c|}{$\%$} \\
\hline \multicolumn{5}{|c|}{ Saflufenacil } \\
\hline Cahill (su) & 1a & $2 a$ & $0 \mathrm{a}$ & 1a \\
\hline GH 4927 (su) & $1 \mathrm{a}$ & $3 a$ & $0 \mathrm{a}$ & $1 \mathrm{a}$ \\
\hline Harvest Gold (su) & $2 \mathrm{a}$ & $4 a$ & $1 \mathrm{a}$ & $1 \mathrm{a}$ \\
\hline Rocker (su) & $1 \mathrm{a}$ & $2 \mathrm{a}$ & $0 \mathrm{a}$ & $0 \mathrm{a}$ \\
\hline BSS $5362\left(s h_{2}\right)$ & $1 \mathrm{a}$ & $4 a$ & $0 \mathrm{a}$ & $1 \mathrm{a}$ \\
\hline GG $236(s u)$ & 1a & $3 a$ & $0 \mathrm{a}$ & $1 \mathrm{a}$ \\
\hline GG 447 (su) & $2 \mathrm{a}$ & $3 a$ & $0 \mathrm{a}$ & $0 \mathrm{a}$ \\
\hline GG $763(s u)$ & $2 \mathrm{a}$ & $4 a$ & $1 \mathrm{a}$ & $1 \mathrm{a}$ \\
\hline \multicolumn{5}{|c|}{ Saflufenacil plus dimethenamid-p } \\
\hline Cahill (su) & $1 \mathrm{a}$ & $2 \mathrm{a}$ & $1 \mathrm{a}$ & $1 \mathrm{a}$ \\
\hline GH 4927 (su) & $1 \mathrm{a}$ & $2 \mathrm{a}$ & $1 \mathrm{a}$ & $1 \mathrm{a}$ \\
\hline Harvest Gold (su) & $2 \mathrm{a}$ & $3 \mathrm{a}$ & $1 \mathrm{a}$ & $2 \mathrm{a}$ \\
\hline Rocker (su) & $2 \mathrm{a}$ & $2 \mathrm{a}$ & $1 \mathrm{a}$ & $2 \mathrm{a}$ \\
\hline BSS $5362\left(s h_{2}\right)$ & $2 \mathrm{a}$ & $3 a$ & $2 \mathrm{a}$ & $2 \mathrm{a}$ \\
\hline GG $236(s u)$ & $2 \mathrm{a}$ & $2 \mathrm{a}$ & $1 \mathrm{a}$ & $2 \mathrm{a}$ \\
\hline GG 447 (su) & $2 \mathrm{a}$ & $2 \mathrm{a}$ & $1 \mathrm{a}$ & $2 \mathrm{a}$ \\
\hline GG $763(s u)$ & $3 a$ & $3 a$ & $2 \mathrm{a}$ & $3 a$ \\
\hline
\end{tabular}

a Abbreviations: $s u=$ sugary; $s h_{2}=$ shrunken endosperm mutant genotype; ${ }^{b}$ Results are averaged for both locations and years; means followed by the same letter within a row for each treatment are not significantly different according to Fisher's Protected LSD test $(\mathrm{P} \leq 0.05)$.
Table 2. Plant height at 3 weeks after emergence (WAE) of eight sweet maize hybrids treated prior to emergence with saflufenacil at 0,75 , and $150 \mathrm{~g} \cdot \mathrm{ha}^{-1}$ or saflufenacil plus dimethenamid-p at 0, 735, and $1470 \mathrm{~g} \cdot \mathrm{ha}^{-1}$ at Exeter, ON, and Ridgetown, ON, in 2008 and 2009.

\begin{tabular}{|c|c|c|c|}
\hline \multirow{3}{*}{ Treatment/Hybrid $^{a}$} & \multicolumn{3}{|c|}{ Plant height } \\
\hline & \multicolumn{3}{|c|}{ Herbicide dose $\left(\mathrm{g} \cdot \mathrm{ha}^{-\mathbf{1}}\right)$} \\
\hline & $\mathbf{0}^{\mathbf{b}}$ & $75 / 735^{b}$ & $150 / 1470^{b}$ \\
\hline & \multicolumn{3}{|c|}{$\mathrm{cm}_{-}$} \\
\hline \multicolumn{4}{|c|}{ Saflufenacil } \\
\hline Cahill (su) & $32 \mathrm{a}$ & $29 \mathrm{a}$ & $28 \mathrm{a}$ \\
\hline GH 4927 (su) & $37 \mathrm{a}$ & $36 \mathrm{a}$ & $34 \mathrm{a}$ \\
\hline Harvest Gold (su) & $32 \mathrm{a}$ & $31 \mathrm{a}$ & $30 \mathrm{a}$ \\
\hline Rocker (su) & $37 \mathrm{a}$ & $35 \mathrm{a}$ & $35 \mathrm{a}$ \\
\hline BSS $5362\left(s h_{2}\right)$ & $28 \mathrm{a}$ & $29 \mathrm{a}$ & $26 \mathrm{a}$ \\
\hline GG $236(s u)$ & $32 \mathrm{a}$ & $32 \mathrm{a}$ & $30 \mathrm{a}$ \\
\hline GG $447(s u)$ & $33 \mathrm{a}$ & $34 \mathrm{a}$ & $32 \mathrm{a}$ \\
\hline GG $763(s u)$ & $25 \mathrm{a}$ & $24 \mathrm{a}$ & $23 \mathrm{a}$ \\
\hline \multicolumn{4}{|c|}{ Saflufenacil plus dimethenamid-p } \\
\hline Cahill (su) & $30 \mathrm{a}$ & $32 \mathrm{a}$ & $31 \mathrm{a}$ \\
\hline GH 4927 (su) & $36 \mathrm{a}$ & $37 \mathrm{a}$ & $35 \mathrm{a}$ \\
\hline Harvest Gold (su) & $34 \mathrm{a}$ & $34 \mathrm{a}$ & $31 \mathrm{a}$ \\
\hline Rocker (su) & $36 \mathrm{a}$ & $37 \mathrm{a}$ & $34 \mathrm{a}$ \\
\hline BSS $5362\left(s h_{2}\right)$ & $27 \mathrm{a}$ & $29 \mathrm{a}$ & $28 \mathrm{a}$ \\
\hline GG $236(s u)$ & $33 a$ & $33 \mathrm{a}$ & $32 \mathrm{a}$ \\
\hline GG 447 (su) & $34 \mathrm{a}$ & $35 \mathrm{a}$ & $33 \mathrm{a}$ \\
\hline GG $763(s u)$ & $24 \mathrm{a}$ & $23 a$ & $22 a$ \\
\hline
\end{tabular}

${ }^{a}$ Abbreviations: $s u=$ sugary; $s h_{2}=$ shrunken endosperm mutant genotype; ${ }^{\mathrm{b}}$ Results are averaged for both locations and years; means followed by the same letter within a row for each treatment are not significantly different according to Fisher's Protected LSD test $(\mathrm{P} \leq 0.05)$.

\subsection{Crop Injury}

Visible injury symptom observed was leaf speckling. Saflufenacil applied PRE at 75 and $150 \mathrm{~g}$ a.i. $\mathrm{ha}^{-1}$ caused minimal injury (4\% or less) in Cahill, GH4927, Harvest Gold, Rocker, BSS5362, GG236, GG447, and GG763 sweet maize at 1 and 2 WAE (Table 1). Similarly, saflufenacil plus dimethenamid-p applied PRE at 735 and $1470 \mathrm{~g}$ a.i. $\mathrm{ha}^{-1}$ caused minimal injury ( $3 \%$ or less) in Cahill, GH4927, Harvest Gold, Rocker, BSS5362, GG236, GG447, and GG763 sweet maize 1 and 2 WAE (Table 1).

Results are similar to those reported in field maize. Soltani et al. (2009) [19] found 1\% or less injury in maize with saflufenacil applied PRE at 50, 100 and $200 \mathrm{~g}$ a.i. ha ${ }^{-1}$. Moran (2010) [20] also found no injury in field maize with saflufenacil applied PRE at 75 and $150 \mathrm{~g}$ a.i. $\mathrm{ha}^{-1}$ or saflufenacil plus dimethenamid-p applied PRE at 735 and $1470 \mathrm{~g}$ a.i. $\mathrm{ha}^{-1}$. Little visible injury seen in different sweet maize varieties evaluated in this study is similar with previous studies on clopyralid [21] and to 
Table 3. Mean weight of marketable cobs at harvest of eight sweet maize hybrids treated prior to emergence with saflufenacil at 0,75 , and $150 \mathrm{~g} \cdot \mathrm{ha}^{-1}$ or saflufenacil plus dimethenamid-p at 0, 735, and $1470 \mathrm{~g} \cdot \mathrm{ha}^{-1}$ at Exeter, $\mathrm{ON}$, and $\mathrm{Ri}$ dgetown, $O N$, in 2008 and 2009.

\begin{tabular}{|c|c|c|c|}
\hline \multirow{3}{*}{ Treatment/Hybrid $^{\mathrm{a}}$} & \multirow{2}{*}{\multicolumn{3}{|c|}{$\begin{array}{c}\text { Mean weight of marketable cobs } \\
\text { Herbicide dose }\left(\mathrm{g} \cdot \mathrm{ha}^{-1}\right)\end{array}$}} \\
\hline & & & \\
\hline & $\mathbf{0}^{\mathbf{b}}$ & $75 / 735^{b}$ & $150 / 1470^{b}$ \\
\hline & \multicolumn{3}{|c|}{$\mathrm{g} / \mathrm{cob}$} \\
\hline \multicolumn{4}{|c|}{ Saflufenacil } \\
\hline Cahill (su) & $302 \mathrm{a}$ & $307 \mathrm{a}$ & $310 \mathrm{a}$ \\
\hline GH 4927 (su) & $307 \mathrm{a}$ & $312 \mathrm{a}$ & $307 \mathrm{a}$ \\
\hline Harvest Gold (su) & $332 \mathrm{a}$ & $343 a$ & $336 \mathrm{a}$ \\
\hline Rocker $(s u)$ & $346 \mathrm{a}$ & $350 \mathrm{a}$ & $345 \mathrm{a}$ \\
\hline BSS $5362\left(s h_{2}\right)$ & $302 \mathrm{a}$ & $315 \mathrm{a}$ & $310 \mathrm{a}$ \\
\hline GG $236(s u)$ & $325 \mathrm{a}$ & $324 \mathrm{a}$ & $325 \mathrm{a}$ \\
\hline GG $447(s u)$ & $398 \mathrm{a}$ & $406 \mathrm{a}$ & $393 a$ \\
\hline GG $763(s u)$ & $341 \mathrm{a}$ & $340 \mathrm{a}$ & $342 \mathrm{a}$ \\
\hline \multicolumn{4}{|c|}{ Saflufenacil plus dimethenamid-p } \\
\hline Cahill (su) & $312 b$ & $303 b$ & $339 a$ \\
\hline GH 4927 (su) & $307 \mathrm{a}$ & $300 \mathrm{a}$ & $303 a$ \\
\hline Harvest Gold (su) & $350 \mathrm{a}$ & $334 \mathrm{a}$ & $349 \mathrm{a}$ \\
\hline Rocker (su) & $347 \mathrm{a}$ & $348 \mathrm{a}$ & $341 \mathrm{a}$ \\
\hline BSS $5362\left(s h_{2}\right)$ & $287 \mathrm{a}$ & $300 \mathrm{a}$ & $304 \mathrm{a}$ \\
\hline GG $236(s u)$ & $309 \mathrm{a}$ & $319 \mathrm{a}$ & $308 \mathrm{a}$ \\
\hline GG $447(s u)$ & $395 \mathrm{a}$ & $398 \mathrm{a}$ & $387 \mathrm{a}$ \\
\hline GG $763(s u)$ & $343 \mathrm{a}$ & $337 \mathrm{a}$ & $344 a$ \\
\hline
\end{tabular}

${ }^{a}$ Abbreviations: $s u=$ sugary; $s h_{2}=$ shrunken endosperm mutant genotype; ${ }^{b}$ Results are averaged for both locations and years; means followed by the same letter within a row for each treatment are not significantly different according to Fisher's Protected LSD test $(\mathrm{P} \leq 0.05)$.

pramezone [22]. However, other herbicides such as bentazon [11], isoxaflutole [17], mesotrione [13], nicosulfuron [14,23], nicosulfuron plus rimsulfuron [24,25], primisulfuron [16], prosulfuron [12] or thifensulfuron-methyl [18] have been shown to cause significant injury in some sweet maize hybrids.

\subsection{Plant Height}

No reduction in plant height was observed for any of the eight sweet maize hybrids treated with saflufenacil or saflufenacil plus dimethenamid-p applied PRE at doses evaluated (Table 2). Plant height was similarly unaffected by increasing herbicide doses.

In other studies, Soltani et al. (2009) [19] reported no adverse effect in field maize height with saflufenacil applied PRE in field maize at dose up to $200 \mathrm{~g}$ a.i. ha ${ }^{-1}$. Lack of any height reduction between sweet maize hybrids evaluated in this study with saflufenacil and saflufenacil plus dimethenamid-p is similar to those found with other herbicides such as clopyralid, halosulfuron
Table 4. Marketable yield of eight sweet maize hybrids treated prior to emergence with saflufenacil at 0,75 , and $150 \mathrm{~g} \cdot \mathrm{ha}^{-1}$ or saflufenacil plus dimethenamid-p at 0,735 , and $1470 \mathrm{~g} \cdot \mathrm{ha}^{-1}$ at Exeter, ON, and Ridgetown, ON, in 2008 and 2009.

\begin{tabular}{|c|c|c|c|}
\hline \multirow{3}{*}{ Treatment/Hybrid $^{\mathrm{a}}$} & \multicolumn{3}{|c|}{ Marketable yield } \\
\hline & \multicolumn{3}{|c|}{ Herbicide dose $\left(\mathrm{g} \cdot \mathrm{ha}^{-1}\right)$} \\
\hline & $\mathbf{0}^{\mathbf{b}}$ & $75 / 735^{b}$ & $150 / 1470^{b}$ \\
\hline & \multicolumn{3}{|c|}{$\mathrm{t} \cdot \mathrm{ha}^{-1}$} \\
\hline \multicolumn{4}{|c|}{ Saflufenacil } \\
\hline Cahill (su) & $14.3 \mathrm{a}$ & $12.4 \mathrm{a}$ & $13.0 \mathrm{a}$ \\
\hline GH 4927 (su) & $15.2 \mathrm{a}$ & $16.4 \mathrm{a}$ & $15.5 \mathrm{a}$ \\
\hline Harvest Gold (su) & $14.5 \mathrm{a}$ & $13.7 \mathrm{a}$ & $13.4 \mathrm{a}$ \\
\hline Rocker (su) & $15.9 \mathrm{a}$ & $17.5 \mathrm{a}$ & $17.3 \mathrm{a}$ \\
\hline BSS $5362\left(s h_{2}\right)$ & $14.2 \mathrm{a}$ & $13.2 \mathrm{a}$ & $12.1 \mathrm{a}$ \\
\hline GG $236(s u)$ & $12.8 \mathrm{a}$ & $12.9 \mathrm{a}$ & $12.4 \mathrm{a}$ \\
\hline GG 447 (su) & $18.8 \mathrm{a}$ & $20.0 \mathrm{a}$ & $19.0 \mathrm{a}$ \\
\hline GG $763(s u)$ & $11.9 \mathrm{a}$ & $12.8 \mathrm{a}$ & $11.5 \mathrm{a}$ \\
\hline \multicolumn{4}{|c|}{ Saflufenacil plus dimethenamid-p } \\
\hline Cahill (su) & $13.2 \mathrm{a}$ & $13.1 \mathrm{a}$ & $13.7 \mathrm{a}$ \\
\hline GH 4927 (su) & $15.3 \mathrm{a}$ & $16.0 \mathrm{a}$ & $15.4 \mathrm{a}$ \\
\hline Harvest Gold (su) & $15.9 \mathrm{a}$ & $15.3 \mathrm{a}$ & $14.6 \mathrm{a}$ \\
\hline Rocker (su) & $17.2 \mathrm{a}$ & $18.0 \mathrm{a}$ & $16.7 \mathrm{a}$ \\
\hline BSS $5362\left(s h_{2}\right)$ & $13.2 \mathrm{a}$ & $14.2 \mathrm{a}$ & $13.8 \mathrm{a}$ \\
\hline GG $236(s u)$ & $13.3 \mathrm{a}$ & $13.8 \mathrm{a}$ & $12.2 \mathrm{a}$ \\
\hline GG 447 (su) & $19.3 \mathrm{a}$ & $21.0 \mathrm{a}$ & $19.4 \mathrm{a}$ \\
\hline GG $763(s u)$ & $12.6 \mathrm{a}$ & $12.8 \mathrm{a}$ & $11.5 \mathrm{a}$ \\
\hline
\end{tabular}

${ }^{a}$ Abbreviations: $s u=$ sugary; $s h_{2}=$ shrunken endosperm mutant genotype; ${ }^{\mathrm{b}}$ Results are averaged for both locations and years; means followed by the same letter within a row for each treatment are not significantly different according to Fisher's Protected LSD test $(\mathrm{P} \leq 0.05)$.

and topramezone $[21,26]$.

\subsection{Cob Size}

Saflufenacil and saflufenacil plus dimethenamid-p applied PRE at doses evaluated caused no decrease in cob size of Cahill, GH4927, Harvest Gold, Rocker, BSS5362, GG236, GG447, and GG763 sweet maize (Table 3). Results in these trials are similar to findings with other herbicides such as halosulfuron which did not caused any negative impact on cob size at $1 \mathrm{X}$ or $2 \mathrm{X}$ of the proposed label dose for any of the sweet maize hybrids studied [26]. However, other studies have shown that cob size of susceptible hybrids can be reduced up to $67 \%$ with clopyralid or thifensulfuron-methyl $[18,21]$.

\subsection{Yield}

Saflufenacil applied and saflufenacil plus dimethenamid$\mathrm{p}$ applied PRE at doses evaluated caused no adverse effect on yield of Cahill, GH4927, Harvest Gold, Rocker, BSS5362, GG236, GG447, and GG763 sweet maize (Ta- 
ble 4). Yield was similarly unaffected by increasing herbicide doses in all sweet maize hybrids evaluated.

In other studies, Soltani et al. (2009) [19] reported no adverse effect in yield with saflufenacil applied PRE in field maize at dose up to $200 \mathrm{~g}$ a.i. $\mathrm{ha}^{-1}$. Moran (2010) [20] also found no yield reduction in field maize with saflufenacil applied PRE at 75 and $150 \mathrm{~g}$ a.i. $\mathrm{ha}^{-1}$ or saflufenacil plus dimethenamid applied PRE at 735 and $1470 \mathrm{~g}$ a.i. $\mathrm{ha}^{-1}$. Yield response with saflufenacil and saflufenacil plus dimethenamid-p are similar to yield response in other herbicides, such as clopyralid [21], topramezone [22] and halosulfuron [26] which were not adversely affected when the herbicide was applied at the label dose. However, other studies have reported significant injury in some sweet maize hybrids with certain herbicides. Diebold et al. $(2003,2004)$ [10] reported up to $94 \%$ reduction in yield with formsulfuron in sweet maize. Similar yield reduction were reported with mesotrione [13], nicosulfuron [14], foramsulfuron [10] and nicosulfuron plus rimsulfuron $[24,25]$ in some sensitive sweet maize hybrids. The potential for and level of crop injury from use of nicosulfuron, mesotrione, and foramsulfuron on any specific sweet maize hybrid is conditioned largely by CYP alleles at the nsf1/ben 1 locus on the short arm of chromosome 5 [27]. However, the sensitivity of sweet maize to other herbicides is controlled by other gene loci. Bentazon metabolism, for example, is controlled by ben1, as well as two independent genes, $\mathrm{Cr} 1$ and $\mathrm{Cr} 2$ [28]. It is hypothesized that sweet maize tolerance to saflufenacil is also conditioned by alternate alleles of the above genes and/or different gene loci, which have, as yet, not been determined.

\section{Conclusion}

Based on this study, the sweet maize hybrids Cahill, GH4927, Harvest Gold, Rocker, BSS5362, GG236, GG447, and GG763 are tolerant to saflufenacil and saflufenacil plus dimethenamid-p applied PRE at doses evaluated. Saflufenacil and saflufenacil plus dimethenamid-p applied PRE to eight sweet maize hybrids had no negative effect on sweet maize injury, height, cob size, or yield. As the dose of saflufenacil or saflufenacil plus dimethenamid-p was increased from $1 \mathrm{X}$ to $2 \mathrm{X}$ of the proposed label dose, there was no negative effect on any sweet maize hybrid. This study shows that saflufenacil and saflufenacil plus dimethenamid-p can be safely applied to these eight sweet maize hybrids at the proposed label dose. The registration of saflufenacil alone or premixed with dimethenamid-p would provide Ontario sweet maize producers with a new, broad-spectrum herbicide that controls selected annual grass and broadleaved weed species. Furthermore, if used in a diversified, integrated weed management program it would reduce the selection intensity for herbicide resistant weeds.

\section{Acknowledgements}

The authors would like to acknowledge T. Cowan and K. McNaughton for their expertise and technical assistance in these studies. Funding for this project was provided by the Ontario Processing Vegetable growers and various seed companies that provided seed.

\section{REFERENCES}

[1] B. McGee, "Area, Production, Value and Sales of Specified Commercial Vegetable Crops," Ontario, 2010. http://www.omafra.gov.on.ca/english/stats/hort/veg_all08 -09.pdf

[2] Ontario Ministry of Agriculture and Food and Rural Affairs (OMAFRA), "Guide to Weed Control," Publication 75, Toronto, 2010, pp. 1-396.

[3] J. C. Frihauf, "Weed Control Efficacy and Winter Wheat Response to Saflufenacil," Ph.D. Dissertation, Kansas State University, Manhattan, 2009.

[4] P. W. Geier, P. W. Stahlman and L. D. Charvat, "Dose Response of Five Broadleaf Weeds to Saflufenacil," Weed Technology, Vol. 23, No. 2, 2009, pp. 313-316. doi:10.1614/WT-08-085.1

[5] S. Z. Knezevic, A. Datta, J. Scott and L. D. Charvat, "Interactions between Saflufenacil and Glyphosate on Selected Broadleaf Weeds," Crop Management, Vol. 14, 2009.

[6] R. A. Liebl, H. Walter, S. J. Bowe, T. J. Holt and D. E. Westberg, "BAS 800H: A New Herbicide for Preplant Burndown and Preemergence Dicot Weed Control," Weed Science Society of America, Vol. 48, 2008, p. 120.

[7] A. S. Senseman, "Herbicide Handbook," 9th Edition, Weed Science Society of America, Lawrence, 2007, pp. $1-493$.

[8] M. Bernards, J. Simmons, C. Guza, C. Schulz, D. Penner and J. Kells, "Inbred Corn Response to Acetamide Herbicides as Affected by Safeners and Microencapsulation," Weed Technology, Vol. 20, No. 2, 2006, pp. 458-465. doi:10.1614/WT-05-130R.1

[9] B. Matthes, J. Schmalfub and P. Boger, "Chloroacetamide Mode of Action II: Inhibition of Very Long Chain Fatty Acid Synthesis in Higher Plants," Zeitschrift für Naturforschung, Vol. 53, 1998, pp. 1004-1011.

[10] S. Diebold, D. Robinson, J. Zandstra, J. O'Sullivan and P. Sikkema, "Sweet Corn (Zea mays) Cultivar Sensitivity to AE F130360," Weed Technology, Vol. 17, No. 1, 2003, pp. 127-132.

doi:10.1614/0890-037X(2003)017[0127:SCZMCS]2.0.C $\underline{\mathrm{O} ; 2}$

[11] S. Diebold, D. Robinson, J. Zandstra, J. O'Sullivan and P. Sikkema, "Sweet Corn (Zea mays) Cultivar Sensitivity to Bentazon," Weed Technology, Vol. 18, No. 4, 2004, pp. 982-987. doi:10.1614/WT-03-156R1

[12] J. O'Sullivan and P. Sikkema, "Sweet Corn (Zea mays) 
Cultivar Sensitivity to CGA 152005 Postemergence," Weed Technology, Vol. 15, No. 2, 2001, pp. 204-207. doi:10.1614/0890-037X(2001)015[0204:SCZMCS]2.0.C $\underline{\mathrm{O} ; 2}$

[13] J. O’Sullivan, J. Zandstra and P. Sikkema, "Sweet Corn (Zea mays) Cultivar Sensitivity to Mesotrione," Weed Technology, Vol. 16, No. 2, 2002, pp. 421-425. doi:10.1614/0890-037X(2002)016[0421:SCZMCS]2.0.C $\underline{\mathrm{O} ; 2}$

[14] J. O'Sullivan, P. Sikkema and R. J. Thomas, "Sweet Corn (Zea mays) Cultivar Tolerance to Nicosulfuron," Canadian Journal of Plant Science, Vol. 80, No. 2, 2000, pp. 419-423. doi:10.4141/P99-066

[15] D. K. Robinson, D. W. Monks, J. R. Schultheis and A. D. Worsham, "Sweet Corn (Zea mays) Cultivar Tolerance to Application Timing of Nicosulfuron," Weed Technology, Vol. 7, 1993, pp. 840-843.

[16] J. O'Sullivan and P. Sikkema, "Sweet Corn (Zea mays) Cultivar Tolerance to Primisulfuron," Canadian Journal of Plant Science, Vol. 82, No. 1, 2002, pp. 261-264. doi:10.4141/P01-079

[17] J. O'Sullivan, R. J. Thomas and P. Sikkema, "Sweet Corn (Zea mays) Cultivar Sensitivity to RPA 2017721," Weed Technology, Vol. 15, No. 2, 2001, pp. 332-336. doi:10.1614/0890-037X(2001)015[0332:SCZMCS]2.0.C $\underline{\mathrm{O} ; 2}$

[18] N. Soltani, P. H. Sikkema and D. E. Robinson, "Sweet Corn (Zea mays) Hybrids Responses to ThifensulfuronMethyl," HortScience, Vol. 40, 2005, pp. 1381-1383.

[19] N. Soltani, C. Shropshire and P. H. Sikkema, "Response of Corn to Preemergence and Postemergence Applications of Saflufenacil," Weed Technology, Vol. 23, No. 3, 2009, pp. 331-334. doi:10.1614/WT-08-120.1

[20] M. E. Moran, "Exploring Preemergence and Postemergence Interactions of Saflufenacil in Field Corn," Ph.D. Dissertation, University of Guelph, Guelph, 2010, pp. 1-
109.

[21] N. Soltani, S. Diebold, D. E. Robinson and P. H. Sikkema, "Sweet Corn Hybrid Sensitivity to Clopyralid," Weed Technology, Vol. 19, No. 2, 2005, pp. 342-345. doi:10.1614/WT-04-121R2

[22] N. Soltani, P. H. Sikkema, J. Zandstra, J. O’Sullivan and D. E. Robinson, "Response of Eight Sweet Corn (Zea mays L.) Hybrids to Topramezone," HortScience, Vol. 42, 2007, pp. 110-112.

[23] C. Morton and R. G. Harvey, "Sweet Corn (Zea mays) Hybrid Tolerance to Nicosulfuron," Weed Technology, Vol. 6, 1992, pp. 91-96.

[24] J. O’Sullivan, R. A. Brammall and W. J. Bouw, "Response of Sweet Corn (Zea mays) Cultivars to Nicosulfuron plus Rimsulfuron," Weed Technology, Vol. 9, 1995, pp. 58-62.

[25] J. O'Sullivan and W. J. Bouw, "Sensitivity of Processing Sweet Corn (Zea mays) Cultivars to Nicosulfuron/Rimsulfuron," Canadian Journal of Plant Science, Vol. 78, No. 1, 1998, pp. 151-154. doi:10.4141/P97-054

[26] S. R. Sikkema, N. Soltani, P. H. Sikkema and D. E. Robinson, "Response of Sweet Maize (Zea mays L.) Hybrids to Halosulfuron," Crop Protection, Vol. 27, No. 3-5, 2008, pp. 695-699. doi:10.1016/j.cropro.2007.09.015

[27] J. K. Pataky, M. D. Meyer, J. D. Bollman, C. M. Boerboom and M. M. Williams II, "Genetic Basis for Varied Levels of Injury to Sweet Corn Hybrids from Three Cytochrome P450-Metabolized Herbicides," Journal of the American Society for Horticultural Science, Vol. 133, 2008, pp. 438-447.

[28] J. N. Nordby, M. M. Williams II, J. K. Pataky, D. E. Riechers and J. D. Lutz, "A Common Genetic Basis in the Sweet Corn Inbred Cr1 for Cross-Sensitivity to Multiple Cytochrome P450-Metabolized Herbicides," Weed Science, Vol. 56, No. 3, 2008, pp. 376-382. doi:10.1614/WS-07-145.1 